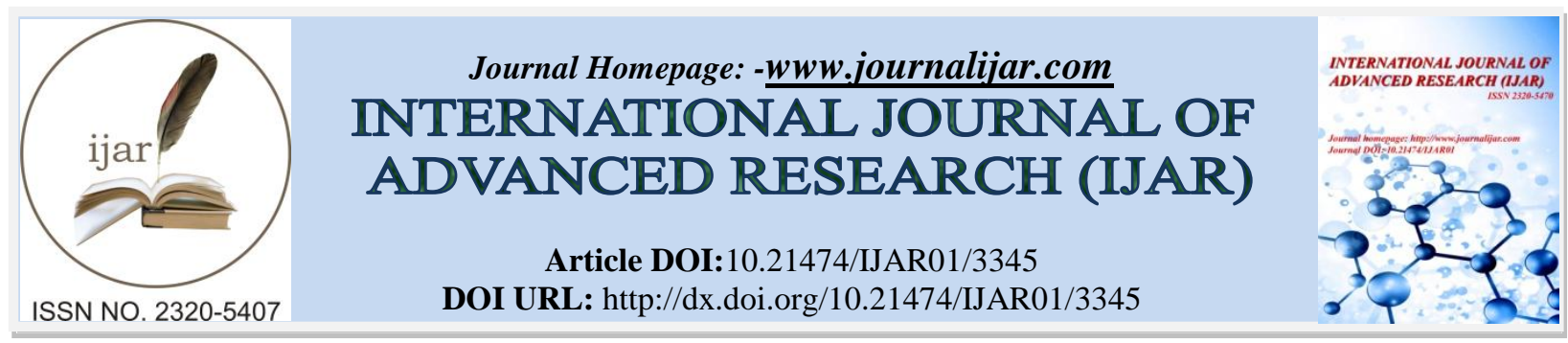

RESEARCH ARTICLE

\title{
FACTORS AFFECTING GROWTH OF SMALL AND MEDIUM ENTERPRISES IN SRI LANKA.
}

\author{
A. U. Amaradiwakara and M. M. Gunatilake.
}

Department of Economics, University of Kelaniya, Sri Lanka.

\section{Manuscript Info}

Manuscript History

Received: 22 December 2016

Final Accepted: 29 January 2017

Published: February 2017

Key words:-

Sri Lanka, SMEs, Growth, Technology, Government.

\begin{abstract}
Small and Medium scale Enterprises (SMEs) play an important role in promoting inclusive growth in the contemporary economy of Sri Lanka. However, the growth and expansion of SMEs are controlled by some unknown factors and those are yet to be revealed. Hence, the main objective of this study was to recognize the factors that influence the growth of SMEs in Sri Lanka. The present study was based on a sample of fifteen SMEs which may have positive or negative growth in sales. The study revealed that the growth of SMEs is constrained by financial inadequacy, the lack of access to new technology, and regulations imposed by the government. Moreover, it was revealed that the level of education of the owner of the enterprise has a direct impact on the growth of SMEs.
\end{abstract}

Copy Right, IJAR, 2017, All rights reserved.

\section{Introduction:-}

Small and Medium scale Enterprises (SMEs) makeup a large part of many economies. They are considered as the backbone of an economy given the fact thatin some economies SMEs contribute to more than $50 \%$ of Gross Domestic Product (ACCA, 2010). Particularly in the European Union, SMEs constitute $99.8 \%$ of all firms and employ around 76 million people representing around 67.4\% of total employment in 2010 (Ayyagari et al. 2011). In the US, SMEs constituted more than 50\% of the non-farm private GDP and created $75 \%$ net new jobs in the economy (ACCA, 2010). Therefore, it is clear that SMEs play an important role in promoting inclusive growth in countries.

The issue of whether small businesses can be considered as beneficial to economic growth must be examined from several different perspectives. As the theory of scale of economies emphasizes, large-scale firms enjoy advantages derived from their economies of scale in production and also from having crossed the threshold of innovative activities, thereby predicting that the resultant increase in the share of large-scale firms will drive economic progress. According to this conventional wisdom which originated back in the days of the industrial revolution, only large firms can meet the requirements of scale efficiency, thus outperforming small firms. It is therefore hypothesized that there is no room for SMEs in those economies pursuing growth, and their future role is expected to diminish (ACS, 1996).

Although precise, up-to-date data are difficult to obtain, estimates suggest that more than $95 \%$ of enterprises across the world are SMEs, accounting for approximately 60\% of private sector employment (Ayyagari et al. 2011). Japan has the highest proportion of SMEs among the industrialized countries, accounting for more than $99 \%$ of total enterprises (EIU, 2010). According to the Ministry of Micro, Small and Medium Enterprises of India, 13 million SMEs were operating in India by 2008 , equivalent to $80 \%$ of all the country's businesses (Ghatak 2010). In South 
Africa, it is estimated that $91 \%$ of the formal business entities are SMEs (Abor and Quartey, 2010). Estimated data for the 27 countries in the European Union (the EU-27) for 2012 also illustrate the importance of SMEs.

The contribution made by SMEs does vary widely between countries and regions. Nevertheless, they play a particularly key role in high-income countries and sometimes even in low-income countries, making significant contributions to both GDP and employment (Dalberg, 2011). They are also major contributors to innovation in economies, partly through collaboration with the larger corporate sector. SMEs that become embedded in the supply chains of larger businesses can be spurred on to improve their own human and technological capital (ACCA, 2010), thus improving their own productivity and performance.

The contribution of SMEs to economic fundamentals nonetheless varies substantially across countries: from 16\% of GDP in low-income countries (where the sector is typically large but informal) to 51\% of GDP in high-income countries. History and legal tradition can also play a very important role for the development of SMEs. For instance, countries that were in the former Soviet Union tend to have disproportionately small SME sectors, even when controlling for per capita income (Ayyagari et al. 2003).

In developing countries, by contrast, over $90 \%$ of all firms outside the agricultural sector are SMEs or microenterprises. These firms produce a considerable part of the GDP. In Morocco, for example, 93\% of industrial firms are SMEs accounting for 38\% of the production, 33\% of investment and 30\% of exports. The contribution of SMEs is considerably higher in South Africa. The estimated $91 \%$ of the formal business entities in South Africa that are SMEs contribute 52-57\% to the GDP. In Ghana, SMEs are even more prominent in the local economy, representing about $92 \%$ of Ghanaian businesses and contributing about $70 \%$ to Ghana's GDP (Abor and Quartey, 2010). Overall, statistics can sometimes mask the particular contribution made by individual sectors. For example, in 2006/7, the contribution made by micro and small businesses to India's GDP was only around 6\%. Even so, manufacturing SMEs accounted for around $40 \%$ of industrial output, and $40 \%$ of all exports (Ghatak, 2010). Similarly, the United States International Trade Commission (2010) reports that SMEs contributed to roughly 50\% of the US private nonagricultural GDP in 2004, a share that had remained relatively stable from 1998 to 2004. The service sectors are by far the most important contributors, accounting for 79\% of SMEs' contribution to GDP . When compared with larger businesses, SMEs' contribution to output tends to be lower per firm because they tend to be more labour intensive than larger firms and concentrated in service sectors. They therefore typically achieve lower levels of productivity, though they do contribute significantly to employment (Wymenga et al. 2011). SMEs' greater labour intensity means that job creation entails lower capital costs than in larger firms(Liedholm and Mead, 1987)which is particularly important for developing countries and economies with high unemployment. Moreover, SMEs are generally more common in rural areas than larger businesses. Especially in developingcountries, SMEs thus provide much-needed employment in rural areas. SMEs can in fact become the engines that sustain growth for long-term development in developing countries. When growth becomes stronger, SMEs gradually assume a key role in industrial development and restructuring. They can satisfy the increasing local demand for services, which allows increasing specialization, and furthermore, support larger enterprises with services and inputs (Fjose et al. 2010).

\section{Literature:-}

Chaston (1995) reported on a 'networking model' for the promotion of the survival and growth of SME sector firms in the UK. The model had been transferred from the Danish Technological Institute, and involved the concept of inter-firm cooperation through the creation of trading networks of SME sector firms. The absence of large firms to initiate and develop the 'trading network' structure was seen as a barrier to the development and growth of firms in the SME sector.O'Gorman (2001) reports on research into the sustainability of growth in SME sector firms and explores the debate between the strategic choice of entrepreneurs which explains SME growth and the industry structure. The author then goes on to consider the cases of two companies in the same industry sector, cash and carry food wholesaling. These companies served the Irish market and their growth and development over a period of 20 years were compared. The study concludes that the strategic choices of entrepreneurs and industry structures are complex and that interaction between the two variables results in combinations that may produce sustained growth. Sparkes and Thomas (2001) investigated the importance of internet developments to the Welsh agro-food sector and concluded that because of peripheral location on the 'Celtic fringe'( some areas in Europe are known as the 'Celtic fringe'), the development and growth of the industry will depend on the ability to take up the marketing opportunities presented by internet technologies. The paper concludes by calling for intervention and support of mechanisms that ought to be deployed in order to enable the industry to appreciate the marketing benefits of adopting e-commerce marketing solutions. 
Choeke and Armstrong (2000) reported on the initial results of a study aimed at investigating the reasons for organizational growth and business success in the SME sector. This work eventually focused on the issue of organizational culture as a factor influencing performance and growth. Empirical evidence is reported from samples in Northwest England and Scotland. The authors' conclusions include suggestions that this research may point to the need to revisit the policy agenda and refocus the nature of advice and assistance initiatives to take into account the influence of organizational culture on SME growth and development.

McLarty (1998) looks at a particular individual case study and examines the characteristics of a successful retail company that have enabled it to enjoy success. The paper concludes that the presence of a marketing approach characterized by marketing planning, the correct marketing mix, the firm's strategic approach and in particular, value chain management have led to the firm's financial success. Within the paper, it is noted that the growth and success is also characterized by reduced turnover per employee and reduced sales per square meter.

Vickers and North (2000) examine the role of a particular intervention, regional technology initiatives on SME sector firms in the English regions. The aim of these initiatives was to enable innovation and technology transfer in the regions and thereby encourage economic development. The initial ideals involved long term strategic partnerships for innovation and technology transfer. However, the reality was that many SMEs really wanted shortterm problem solving assistance rather than to avail themselves of long term innovation and technology transfer opportunities. Thus, a number of researchers have reported on work in the SME sector and have sought to diagnose the extremely important areas that SME managers may look to for success. Policymakers have also been involved in interventions to encourage SME development and growth. This activity has been a widespread and global phenomenon.

\section{Small and Medium Enterprises in Sri Lanka:-}

SMEs encompass establishments operating in agriculture, mining, manufacturing construction and service sectors. However, its relative significance in the national economy cannot be estimated due to lack of information. With respect to SMEs however the existing database is more reliable and hence it is possible to give some indication of the size of the sector on comparative basis.

Although SMEs in Sri Lanka contributed an estimated 40\% to the GDP during the period from 2010 to 2012, it is likely that the potential negative impact on GDP growth stemming from the high borrowings in SMEs was significant (CBSL, 2012). Sometimes high borrowings are a consequence of high growth in business. As a result of high borrowings, during 2010 and 2011, the Sri Lankan economy grew by $8 \%$ and $8.2 \%$ respectively and that was the highest GDP growth rates recorded in over three decades. During that period, loans to SMEs grew by $68.3 \%$ in 2011 (CBSL, 2012).Such an increase in borrowing needs to be supported with equity to make sure growth is sustainable but it was not the case in Sri Lanka. As a result of high borrowings, during the 2010-2011 period, the growth records of Sri Lankan SMEs were lagged. According to the Sri Lankan Enterprise Survey, the growth rate of Sri Lankan SMEs was 2.9\% and it is very low compared to the world 5.2\% (Hettiarachchi, 2013).Many investigations into SMEs prove that high proportions of new ventures have closed down during their first years of life. This indicates that these firms were not able to maintain the position with their environment or never achieved it.So, it is clear that even though business owners start their ventures with the best of intentions and work long, hard hours, some of the businesses survive but others fail.

There is no recently conducted industrial survey to identify the strengths, weaknesses, threats and opportunities of SMEs. The Department of Census and Statistics of the Ministry of Finance and Planning has being conducting annual industrial surveys but it has not covered the establishments with less than 5persons engaged. Subject to that limitation, the most recently conducted industrial survey dates back to 1997. According to the Annual Survey of Industries(1998) conducted by the Department of Census and Statistics of Sri Lanka, the majority of establishments stem from small businesses but their contribution to the economy is very low (about 6\%). On the other hand, there are only $2 \%$ of large scale establishments and their contribution is much higher which accounts to more than $50 \%$ of output. Therefore, it is clear that although there are large numbers of SMEs in Sri Lanka, their contribution to the national economy in terms of output and share in employment has been very low. It is essential to recognize the contribution of SMEs in other developing and developed countries to come up with a proper conclusion.

Therefore it is clear that in other developing or developed countries, the SME sector contributes to a large proportion of the country's GDP whereas in Sri Lanka it has not achieved its anticipated results. Hence, it is clear that there is a 
need for the future improvement of this sector in Sri Lanka and it is also essential to identify the ways to harness the full potential of this sector.

Unfortunately, there is no commonly accepted definition for SMEs. Different countries use different parameters to define SMEs such as number of employees, amount of capital invested, amount of turnover, etc. Different definitions are also used by different organizations within the same country to define SMEs for different purposes and this is common in Sri Lanka as well. Table 1 shows definitions of SMEs in Sri Lanka by different authorities.

Table 1:- Definitions of SMEs in Sri Lanka

\begin{tabular}{|c|c|c|c|}
\hline Institution & Criterion & Medium Scale & Small Scale \\
\hline $\begin{array}{l}\text { Sri Lanka Standards } \\
\text { Institution (SLSI) }\end{array}$ & No. of Employees & Between 50 - 249 & Less than 50 \\
\hline $\begin{array}{ll}\text { Industrial Development } \\
\text { Board (IDB) }\end{array}$ & Value of Machinery & $\begin{array}{l}\text { Between Rs. } 4 \text { Million to } \\
10 \text { Million }\end{array}$ & Less than Rs. 4 Million \\
\hline 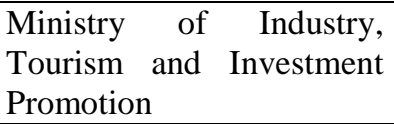 & $\begin{array}{l}\text { Value of fixed assets other } \\
\text { than land and buildings }\end{array}$ & Up to Rs. 16 Million & Less than Rs. 16 Millions \\
\hline $\begin{array}{l}\text { Federation of Chambers of } \\
\text { Commerce and Industry of } \\
\text { Sri Lanka }\end{array}$ & Capital employed & $\begin{array}{l}\text { Between Rs.2 Million to } \\
20 \text { Million }\end{array}$ & Less than Rs. 2 Million \\
\hline $\begin{array}{l}\text { Ministry of Small and } \\
\text { Rural Industries }\end{array}$ & Total Investment & $\begin{array}{l}\text { Between Rs. Million } 20 \text { to } \\
50 \text { Million }\end{array}$ & $\begin{array}{l}\text { Between Rs. } 1 \text { Million to } \\
20 \text { Million }\end{array}$ \\
\hline $\begin{array}{l}\text { Ceylon National Chamber } \\
\text { of Industries }\end{array}$ & $\begin{array}{l}\text { i) Value of assets other } \\
\text { than buildings and lands. } \\
\text { ii) No. of employees }\end{array}$ & $\begin{array}{l}\text { Between Rs. } 4 \text { Million to } \\
\text { Rs. } 20 \text { Million } \\
\text { Between } 10-50\end{array}$ & $\begin{array}{l}\text { Less than Rs. } 4 \text { Million } \\
\text { Less than } 10\end{array}$ \\
\hline $\begin{array}{lr}\text { Sri Lanka } & \text { Export } \\
\text { Development } & \text { Board } \\
(\text { EDB) } & \end{array}$ & $\begin{array}{l}\text { i) Capital investment } \\
\text { excluding lands and } \\
\text { building } \\
\text { ii) Annual export turnover }\end{array}$ & $\begin{array}{l}\text { More than Rs. } 40 \text { Million } \\
\text { More than Rs. } 100 \text { Million }\end{array}$ & $\begin{array}{l}\text { Less than Rs. } 20 \text { Million } \\
\text { Less than Rs. } 100 \text { Million }\end{array}$ \\
\hline $\begin{array}{l}\text { World Bank (for Sri } \\
\text { Lankan country studies } \\
\text { and loan programmes) }\end{array}$ & No. of employees & Between 50-99 & Less than 1- 49 \\
\hline $\begin{array}{l}\text { Dept. of Census and } \\
\text { Statistics }\end{array}$ & No. of Employees & $\begin{array}{l}\text { More than } 25 \text { (Year } 2000) \\
\text { More than } 10 \quad \text { (Year } \\
2003 / 04)\end{array}$ & $\begin{array}{l}\text { Less than } 25 \text { (Year } 2000) \\
\text { Less than } 10 \text { (Year } \\
\text { 2003/04) }\end{array}$ \\
\hline $\begin{array}{l}\text { Task Force for SMEs } \\
\text { Development in Sri Lanka } \\
(2002)\end{array}$ & $\begin{array}{l}\text { Asset Value excluding } \\
\text { land and buildings value }\end{array}$ & $\begin{array}{l}\text { Not exceeding more than } \\
\text { Rs. } 50 \text { Million }\end{array}$ & $\begin{array}{l}\text { Not exceeding more than } \\
\text { Rs. } 20 \text { Million }\end{array}$ \\
\hline $\begin{array}{l}\text { Sri Lankan Apparel } \\
\text { Industry, Task force on } \\
\text { five year strategy (2002) }\end{array}$ & $\begin{array}{l}\text { i) Export value } \\
\text { ii) No. of Employees }\end{array}$ & $\begin{array}{l}\text { Rs. } 101 \text { Million to } 250 \\
\text { Million } \\
1-100\end{array}$ & $\begin{array}{l}\text { Rs. } 0.25 \text { Million to } 100 \\
\text { Million } \\
101-250\end{array}$ \\
\hline $\begin{array}{l}\text { The Dept. of Small } \\
\text { Industries }\end{array}$ & $\begin{array}{l}\text { i) Capital investment } \\
\text { ii) No. of Employees }\end{array}$ & $\begin{array}{l}\text { Between Rs. } 25-5 \\
\text { million } \\
\text { Between } 100-50 \\
\end{array}$ & $\begin{array}{l}\text { Less than Rs. } 5 \text { Million } \\
\text { Less than } 50 \text { employees }\end{array}$ \\
\hline
\end{tabular}

Source:Dasanayaka, S.W.S.B.(2009).Measuring the Informal Economy in Developing Countries.

SMEs are considered as the heart of the economy. Therefore many successive Sri Lankan governments have taken steps to develop this vital sector. However, when analyzing the present contribution of this sector to the national economy it seems that it has not produced the desired results. The reasons for this have been identified by conducting several surveys. The banking survey of the SME market in Sri Lanka (2006-07) of the International Finance Corporation (IFC) listed five principal constraints of the SME factor. They were (a) difficulties in obtaining finance (b) absence of technical and management skills (c) marketing constraints (d) inadequate infrastructure facilities for production and (e) outdated technology. According to the survey, one of the most common constraints to growth was the requirement of banks of collateral when providing credit facilities. 
It concludes that the main reason for the lack of growth in SMEs is the shortage of capital due to a number of reasons such as the lack of access to banking facilities, the lack of knowledge on banking procedures and the inability to provide guarantees. Hence, this investigation will analyze the capital structures of SMEs and the factors influencing the growth of SMEs in Sri Lanka. By examining the problems associated with the development of this sector, this study will also attempt to identify the measures that can be taken to mitigate the identified problems.

\section{Methodology:- \\ Measuring the Growth:-}

The growth of SMEs can be measured in various ways. In accordance with government policy research as well as many management and economic sources, growth is measured in terms of increase in the number of employment in the SME sector. This measure has been of the most relevance to many government policy makers since SME growth has been seen as an important way of reducing unemployment. Nevertheless, owners and managers of SMEs are usually interested in financial performance rather than in employment growth. This can be measured by the growth of sales or turnover growth and profitability.

Various measures of profitability can be used such as absolute profitability, profitability per employee, profitability as a percentage of turnover or percentage change in profitability. Profits are necessary for survival in the long run in a competitive environment, but SME management may choose not to grow. Long-term profitability derives from the relations between cost and revenue. It is a necessary but insufficient condition for growth. Revenues may be held up by entry barriers and costs pushed down by management skills. A low-profit firm will lack the finance for expansion, but a high-profit business may conclude that when taking into consideration the risks of expansion, its rewards are inadequate. In a 'life style' SME, an owner may trade profitability today against profitability tomorrow. Dynamic pricing or sequential investment projects may initially require lower profits in order to obtain higher future pay-offs from greater market penetration. Therefore profit performance must be standardized against the size of the operation or the resources employed.

In this research used a measure of SME growth which is percentage change in SME turnover. Other measures of firm growth that could be used are market share, percentage change in employment, return on capital employed and measures of productivity. Growth can also take the form of personal development of managers and employees, technology innovation and professional recognition.

\section{Population and the Sample:-}

The population of this study is based on SMEs in different sectors such as food, garments, metal and machinery etc. in the Gampaha District in the Western Province of Sri Lanka. The Western Provincewas chosen for this study since it has a large number of SMEs. The survey sample includes 100 enterprises. As the study is only related to the small and medium sized category, the enterprises that belong to the large category were excluded. The sample was selected with the use of the stratified sampling method.

\section{Data and Sources of Data:-}

An amalgamation of primary and secondary data used in the analysis. Primary data were collected through a questionnaire and face to face informal interviews with SME owners. Secondary data were collected through research articles, Census and Statistics Department publications, debt financing institutions, CBSLannual reports and the internet.

\section{Analytical Tools and Techniques:-}

Statistically testable hypotheses weredeveloped to test the independence and the correlation of variables which have identified as the influential variables on the growth and expansion of SMEs by the previous studies. Thus, it is important to have a knowledge of the statistical methods used in prior researches in this area in order to select the most effective method to be used in the above study.

\section{Variables and Definitions of Variables:-}

The factors affecting the growth of SMEs have been identified by the previous research. The variables and definitions of those variables are given below.

Size of the firm: Firm size is determined by the number of employees of a firm. Small enterprises have been defined as those with fewer than 20 employees.Medium size enterprises comprise of 20-99 employees. 
Age of the firm: The number of years in business has been identified as an important variable in previous studies as it determines the credit-worthiness of the business. The information required by the lenders at the time of granting credit may be limited for younger firms due to the lack of an established track record. Hence, the transaction costs associated with lending to younger firms are likely to be relatively high. Furthermore, the younger firms may not be able to offer collaterals acceptable to the banks as those firms have not accumulated sufficient fixed assets.

Sector: The sectors were classified into five categories namely food, garments, metal and machinery, non-metallic and plastic materials and textiles. If a business does not fall into one of the above categories it can specify its business.

Ownership type: Firms were classified into six organizational types in the survey: sole proprietorships, partnerships, private-held limited company, and publicly-listed company, cooperative and other.

Location: Location is classified based on the distance to the capital city.

Sales value: The growth of sales value is considered as a variable which shows the growth of SMEs. It identifies the growth of SMEs by analyzing the sales value of last two consecutive years of the business. If there is a positive growth in sales $=1$; a negative growth in sales $=0$.

Availability of audited financial statements: If the firm has audited financial statements $=1$. If the firm does not have audited financial statements $=0$.

Capital requirements: The funding of the business is evaluated under this variable. Financial feasibility of the business will be addressed.

Level of Education of the owner: Education of the principle owner is redefined by categories from (a) to (d), corresponding to whether the owner has not completedsecondary school, vocational training, a university graduate degree and/or postgraduate degree. Education may be proxy for unobserved managerial ability.

Entrepreneur's experience and skills of the employees: The variable is measured by considering the number of years of business experience they possess in the previous business and the current business at the time of the survey. If the entrepreneur is well experienced he/she will be more successful in analytical and management skills. Skilled employees are essential for a business to be effective and efficient. This will lead to a positive growth in the business.

Technology: Technology is the key to sustain any business in the long run. If a business produces innovative products in a well- timed manner, current customers will have faith in the business and more customers will be attracted to the business.

Availability of raw materials: This variable identifies the obstacles encountered when obtaining raw materials such as tariffs, import duties, etc. When the business is compelled to incur a large cost to obtain raw materials this will have a direct impact on the sales value of the business.

Competition: The business needs to identify its competitive rivalry. It will have a positive as well as a negative impact on the growth of SMEs. If the competition is high, businesses will try to improve themselves in order to meet the competition. However, high competitiveness will impact on the quality of the product and as a result,the businesses will lose their customers in the long run. Therefore the competition has a direct impact on the sales value of the business.

Support of the government: If the government is willing to improve the SME sector in the country and has already taken initiatives to develop this vital sector, it will clearly lead to a positive growth of SMEs

Networking: Entrepreneurial networks are defined in this study as entrepreneurs' personal relationships with external parties. The networking ability in this study was measured by their participation in networks such as business association and/or chamber of commerce. If a business is a part of a network it will get more up-to-date information about the industry. 


\section{Data Analysis and Results:-}

Statistically testable hypotheses are formulated to express the possible relationships between the growth of SMEs and the factors identified.

Hypothesis $1 . \quad \mathrm{H}_{\mathrm{O}}$ : Technology does not have an impact on the growth of SMEs

$\mathrm{H}_{\mathrm{A} \text { : }}$ Technology does have an impact on the growth of SMEs

Hypothesis $2 \quad \mathrm{H}_{\mathrm{O}}$ : Financial constraints do not impact on the growth of SMEs

$\mathrm{H}_{\mathrm{A}}$ : Financial constraints have an impact on the growth of SMEs

Hypothesis 3. $\quad \mathrm{H}_{\mathrm{O}}$ : Education level of the owner does not have an impact on the growth of SMEs

$\mathrm{H}_{\mathrm{A}}$ : Education level of the owner does have an impact on the growth of SMEs

Hypothesis $4 \quad \mathrm{H}_{\mathrm{O}}$ : Purchase of raw materials does not have an impact on the growth of SMEs

$\mathrm{H}_{\mathrm{A}}$ :Purchase of raw materials doeshave an impact on the growth of SMEs

Hypothesis 5. $\quad \mathrm{H}_{\mathrm{O}}$ : Age of the company does not have an impact on the growth of SMEs

$\mathrm{H}_{\mathrm{A}}$ : Age of the company does have an impact on the growth of SMEs

Hypothesis 6. $\quad \mathrm{H}_{\mathrm{O}}$ : Competition rivalry does not have an impact on the growth of SMEs

$\mathrm{H}_{\mathrm{A}}$ :Competition rivalry does have an impact on the growth of SMEs

Hypothesis 7. $\quad \mathrm{H}_{\mathrm{O}}$ : Years of experience as an entrepreneur do not have an impact on the growth of SMEs.

$\mathrm{H}_{\mathrm{A}}$ :Years of experience as an entrepreneur doeshave an impact on the growth of SMEs.

\section{Technology and growth in sales}

The Pearson Chi-Square statistic (11.484) with a significant value of 0.001 is below the alpha level (0.05). This suggests that a statistically significant relationship does occur between the technology and growth in sales. Therefore, Hypothesis 1, which is the null hypothesis, is rejected.

\section{Fulfillment of capital requirement and growth in sales}

The Pearson Chi-Square statistic (5.529) with a significant value of 0.19 is below the alpha level (0.05) which suggests that there is evidence to prove that there is a significant relationship between the capital requirement fulfillment of the SME and the growth in sales. As a result we can reject the null Hypothesis 2.

\section{Level of education of the owner and growth in sales}

As might be expected, firms with educated owner-managers are more likely to grow presumably due to their knowledge in the strategies. The value of the Chi-Square statistic is 3.233. This indicates that this value is less than the tabulated value and thus, it is not significant. The significant value is 0.072 and it is higher than the alpha value (0.05). This indicates that there is no relationship between the level of education of the owner and the growth in sales. Therefore the hypothesized relationship (Hypothesis 3 ) is accepted.

\section{$I V$. Obtaining raw materials and growth in sales}

Somewhat surprisingly, it was found that there is no significant association between obtaining raw materials and growth in sales because the Pearson Chi-Square statistic is 0.134 and the significant value is 0.714 which is much higher than the alpha value (0.05). Hence the Hypothesis 4 is accepted.

\section{$V$. Age of the company and growth in sales}

The result of this survey suggests that there is no relationship between the age of the firm and the growth in sales as the Pearson Chi-Square statistic is 0.603 and the significant value is 0.438 which is higher than the alpha value (0.05). Therefore, null Hypothesis 5 is accepted. However, according to the literature review, more mature firms have a significant influence over the growth of sales of the firm.

\section{Competition rivalry and growth in sales}

Hypothesis 6 states that "competition rivalry does not impact on the growth of sales". According to the Pearson ChiSquare, the variable is statistically not significant with a Chi-Square statistic of 0.010 with a significant value of 0.919 which is higher than the alpha value (0.05).Hence, Hypothesis 6 is accepted.

VII. Years of experience as an entrepreneur and growth in sales

The Pearson Chi-Square statistic is 0.719 and the significance value is 0.714 which is higher than the alpha value (0.05). Hence, Hypothesis 7 which indicates that there is no relationship between the experience of the entrepreneur and the growth in sales is accepted with a 95\% confidence level, it can be concluded that the technology and financial constraints have a direct impact on the growth of sales whereas other factors such as the education level of 
the owner, issues in obtaining raw materials, age of the company, competition rivalry and the experience as an entrepreneur do not have an impact on the growth in sales of the enterprise.

\section{Correlation analysis:-}

The correlation analysis is also used to recognize the possible relationships between the growth of SMEs and the identified independent variables. The results of the correlation analysis are as follows:

Considering the growth in sales and the required technology, the coefficient of correlation is 0.875 . It shows that the two variables have a strong positive correlation with each other. The fulfillment of required amount of capital and the growth in sales have a correlation coefficient of 0.607. It indicates that the two variables have a positive correlation with each other. The coefficient of correlation between the level of education and the growth in sales is 0.464. The correlation between these two variables is a weak positive correlation. According to the correlation analysis, coefficient of correlation between the growth in sales and the raw materials is -0.094 . It shows that these two variables have a weaknegative correlation with each other. Similarly, the variables of growth in sales and the age of the company shows a weak negative correlation (-0.200). The two variables, growth in sales andcompetition rivalry confirms a weak positive correlation (0.026). The coefficient of correlation between the growth in sales and the years of experience as an entrepreneur is -0.094. This result implies that these two variables have a weak negative correlation but it is somewhat unrealistic.

\section{Case Studies:-}

Case Study - I: Diligent Products and Solutions:-

Mr. and Mrs. Fernando are not just partners in business, but in life too. The husband-wife duo operate a major business line calledDiligent Productsand Solutions. Being an MBA holder Mr. Fernando has been involved in many careers. However, he has always had a flair for drawing. He realized that he could convert this skill into a part-time profitable business by creating personally-designed furniture to suitfor the international market. His wife was supportive of this decision and helped him to make his dream a reality.

For over a decade they have been able to successfully deliver their products to their loyal customers. In the earlier stages, the company was going through difficulties. However, later on, the duo were able to recover from this unfortunate situation and as a result, they are now one of the leading businesses in the industry. Diligent Products and Solutions has maintained a steady growth throughout the past years even though the owners have taken out a few loans with high interest rates.

However, the company's financial statements are not audited. Mr. Fernando says;

"Because it's a family business and I, myself is involved in the business there is no point of auditing. Also, auditing leads to the compulsion to pay taxes such as VAT, etc. Hence, I don't audit my financial statements".

He believes that the reason for his success is the relationship he has with his workers. He finds it easy to find skilled workers due to this close relationship. He says;

"Attitudes of the workers matter a lot".

Currently, he does not have new technology but he admits that he has all the required technology within the company. Furthermore, he has a website to promote his products and through that he has been able to expand the customer base. His major concern is about the raw materials. Timber is obtained from the Timber Cooperation. However, the quality of the timber is questionable. Further, he explains that at times due to the restrictions imposed by the government on the transportation of timber they have to bribe some of the dealers. Caster wheels and other equipment which are needed to develop the timber product have to be imported from agents. Consequently, there is a problem of obtaining raw materials when the company is in need and also result in high cost.

The company faces no competition as it depends only on contacts. Hence Mr. Fernando believes that the company can handle the capacity to meet the demand its own. When asked about the secret to their success he pointed out;

"It is about making the right product available at the right time, as well as at the right place”.

Over time, their business has evolved and expanded across other categories such as providing strategic business solutions to private companies. 


\section{Case Study - II: ShelloCosmetics Company Private Limited:-}

Mr.VipulaGunarathne, the owner of Shello Cosmetics Private Limited shared his success story with us. Being a graduate from the University of Kelaniya with experience in Australia regarding chemicals, he decided to get into the cosmetics industry. For more than a decade he has been successful in his business because of top quality products at a standard price and good presentation of the products. As he is well-educated, the financial statements of the company are audited.

The capital requirement for the company has been fulfilled by loans. The company has to allocate $10 \%$ from the monthly total income to settle down the loan interest and other capital requirements. He admits sometimes it takes up time to pay the due amount on time because it is difficult to collect money from the clients who bought goods on credit. Thereby he uses jewelry pawning, credit cards etc. to pay the due amount.

Shello Cosmetics has been able to acquire completely new technology during past few years which has paved the way for it to be a leading company in the industry. He says;

"We have the required technology but we do not have knowledge in some areas, for instance, advertising. So we are looking forward to improving our knowledge in such areas".

The main problem the company faces is obtaining raw materials. Mr. Gunarathnesays;

"Sometimes we only need very small quantities of certain chemicals but we cannot import the exact quantity we need due to government regulations".

He further explained that due to the lack of advertising skills and poor market conditions, the company might be affected adversely in the future. However, currently the company is one of the leading cosmetics companies in Sri Lanka. It aims to grow further in the future.

\section{Conclusion:-}

The growth of Sri Lankan SMEs are closely associated with a number of factors. The present study revealed that some factors have adversely affected the growth of SMEs in Sri Lanka. Financial inadequacy is a factor which has significantly constrained the growth and expansion of the SME sector in Sri Lanka.The lack of access to new technology is another vital factor which has limited the growth and expansion of SMEs.However,access to new technology is directly linked to the availability of financial resources. Government regulations on imports and exports, particularly imposed duties and restrictions on certain raw materials also act as limitations on the growth and expansion of SMEs. This study also revealedthat the level of education of the owner of the enterprise has a direct impact on the growth of SMEs. Moreover, this study revealed that the majority of Sri Lankan SMEs have little access to the international market and serve only the domestic market whichin turn has had a negative impact on the expansion of SMEs.

\section{References:-}

1. ACCA (2010), Small Business: A Global Agenda. www.accaglobal.org.uk/content/dam/acca/global/PDF-technical/small-business/pol-afb-sbaga.pdf.

2. Acs, Z.J. (1996). Small Firms and Economic Growth, Edward Elgar, Cheltenham.

3. Abor, J \&Quartey,P (2010). 'Issues in SMEs in Ghana and South Africa', International Research, Journal of Finance and Economics, Issue 39, pp.218-228.

4. Ayyagari, M., Demirgüç-Kunt, A. \&Maksimovic, V. (2011), Small vs. Young Firms Across The WorldContribution to Employment, Job Creation, and Growth, Policy Research Working paper 5631 (The World Bank Development Research Group).

5. Central Bank of Sri Lanka. Annual Reports, 1996-2012.

6. Chaston, I. (1995). 'Danish Technological Institute SME Sector Networking Model', Journal of European Industrial Training, Vol. 19 (1), pp. 10-17.

7. Choueke, R. \&Armstrong, R. (2000). 'Culture: a Missing Perspective on Small and Medium-sized Enterprise Development', International Journal of Entrepreneurial Behavior and Research, Vol. 6(4), pp227-238.

8. Dasanayaka, S. W. S. B. (2009). Measuring the Informal Economy in Developing Countries. Special IARIWSAIM Conference, Kathmandu, Nepal, September 23-26. Retrieved from http://www.iariw.org. 
9. Dalberg (2011), Report on Support to SMEs in Developing Countries Through Financial Intermediaries, SME Briefing Paper, EIB Draft Version (Geneva: European Investment Bank).

10. Davidson. P, \& Griffin, R.W. (2003). Management, An Australian Perspective (Second Edition), John Wiley and Sons, Brisbane, Australia.

11. EIU (2010), SMEs in Japan: A New Growth Driver?, http://www.eiuperspectives.economist.com/pdf.

12. Fjose S., Grunfeld L. A. \& Green C. (2010). SMEs and Growth in Sub-Saharan Africa. Identifying SME Roles and Obstacles to SME Growth. MENON Business Economics Publication no. 14/2010.

13. Ghatak, S. (2010), Micro, Small and Medium Enterprises (MSMEs) in India: An Appraisalwww.legalpundits.com/Content_folder/SMEArti150610.pdf

14. Hallberg,K.,(2000).A Market Oriented Strategy for Small and Medium Scale Enterprises: World Bank, Washington.

15. Hettiarachchi, I. (2013).Time to Reduce Borrowings in Sri Lankan Enterprises. (Online) Available: http://www.dailymirror.lk/business/features/33710-time-to-reduce-borrowings-in-sri-lankan-enterprises.html.

16. Liedholm, C. \& Mead, D. C. (1987) Small Scale Industries in Developing Countries: Empirical Evidence and Policy Implications. MSU International Development Paper No. 9. Michigan State University Department of Agricultural Economics, East Lansing, Michigan.

17. McLarty, R. (1998). 'Case study: Evidence of a Strategic Marketing Paradigm in a Growing SME', Journal of Marketing Practice, Applied Marketing Science. Vol. 4 (4), pp105-117.

18. O'Gorman, C. (2001). 'The Sustainability and Growth in Small and Medium Sized Enterprises',International Journal of Entrepreneurial Behavior and Research, Vol. 7 (2), pp 60-75.

19. Sparkes, A \& Thomas, B. (2001). 'The use of the Internet as a Critical Success Factor for theMarketing of Welsh Agri-food in the Twenty-first Century', British Food Journal, Vol. 105(5),pp.331-347.

20. United States International Trade Commission (2010), Small and Medium-Sized Enterprises: Overview of Participation in US Exports, Investigation No. 332-508. USITC Publication 4125, January.

21. Vickers, I \& North, D. (2000). 'Regional Technology Initiatives: Some Insights from the English Regions', European Planning Studies, Vol. 8 (3), pp 301-318.

22. Wymenga, P., Spanikova, V, Derbyshire, J \& Barker, A (2011).Are EU SMEs recovering? Annual Report on EU SMEs 2010/2011, Rotterdam, Cambridge. 